\title{
The Effect of Family Ownershipnd CEO Characteristics n Foreign Investmentof Publicly Listed Family Firms
}

\author{
Annisa Sabila ${ }^{1}$ and Viverita ${ }^{2}$ \\ ${ }^{1,2}$ Department of Management, Faculty of Economics and Business, Universitas Indonesia, Indonesia
}

${ }^{1}$ Annisasbl8@gmail.com, ${ }^{2}$ viverita.d@ui.ac.id

\begin{abstract}
This study aims to analyze the effect of family ownership and CEO characteristics on foreign investment of the Indonesian publicly listed family firm.CEO characteristics are proxied by three variables which are CEO founder and CEO descendant, CEO education, and CEO background.This study uses the purposive sampling of family firms which divided into two categories, group and standalone.By using the Random effect model, this study founds that family ownership significantly lessen foreign investment due to the risk of expropriation and high monitoring cost.This effect is more pronounced in standalone firms rather than firms within a group.On the other hand, higher CEO education brings more foreign investment. In addition dividend and board size reduced foreign investment meanwhile firm's profits and crisis increased foreign investment.
\end{abstract}

Keywords: Foreign Investment, Family Ownership, CEO

\section{Introduction}

The worldwide phenomenon of liberalization encouraged foreign investment as the crucial source of capital in any market. Foreign investment was particularly essential in emerging markets where the capital market is yet to be developed [1]In addition, emerging markets offer more attractive opportunities to foreign investors compared to developed markets, because of their relatively higher growth prospects [2] Of the eight emerging markets recorded by International Monetary Fund, Brazil has the highest amount of net portfolio equity inflow whereas Indonesia is in the fifth place although foreign investment amount of $60 \%$ of total portfolio investment of the listed firms owned by foreigners (Detik Finance). Foreign investment defined as a ratio of the number of shares held by foreign investors to outsider ownership, including the mutual fund, retail investors, and banks, etc., which maximum share ownership of up to 95 percent

One of the attractive factors by foreign investors is the corporate governance $(\mathrm{CG})$ both of the firm and the country where those firms operate [3]; [4]). CG is traditionally defineas a relationship between the principal (shareholder) and agent (manager) [5]. There are four major values of CG framework: fairness, responsibility, transparency, and accountability. Those values lead to a discussion about shareholders and board of directors. Shareholders are related to controlling shareholders which defined as shareholders who have the highest voting rights in a company or 
shareholders who able to affect firms' activities in other ways International Finance Corporation. Meanwhile, controlling shareholders often associated with family-owned firms or family firms.

There is a large number of developing countries in Asia whose majority of the company's shares is held by their founder of the family of the founder or commonly referred to family firms. A family firm is a company with no less than 25 percent of shares voting rights owned by the founder or family members [6]In India, the founder's holdings affect foreign investment on an inverted U-shaped basis due to alignment and entrenchment effect, whereby this influence is greater in companies within a business group [1]At the same time, there is a negative relationship between control-ownership disparity on foreign investment in Korean firms and the higher impact on companies incorporated in Chaebol Group [7]In Indonesia, many companies are more dominated by family firms. They accounted for more than 95 percent in Indonesia [8]. Therefore, the issue of transparency and regulation are relatively weak[9]. Their cash flow rights are more concentrated compared to companies in other East Asian countries [10]

The OECD framework for corporate governance suggests the importance of accountability of the board of directors and its shareholders in the implementation of good corporate governance. Mace [11]advice that the board of directors is only in charge of following all the decisions taken by the Chief Executive Officer (CEO). Zahra \& Pearce [8]found that CEOs have enormous organizational power to influence financial decision making and to monitor the planning and implementing of strategies. Several studies have analyzed the influence of CEO characteristics on firm managerial decisions in the short and long term. The three CEO characteristics discussed in this study are related to generation, education, and business expertise.

A survey conducted by the Price Waterhouse Coopers [8]found that family firms in Indonesia controlled by $23 \%$ of the first generation, $37 \%$ by the second generation, and $33 \%$ by the third generation respectively. Some of the second and third generations still manage the company professionally and successfully. For example, such as Noni Purnomo (the third generation) in Blue Bird; Bryan Tilaar and Putri Kus Wisnu Wardhani (the second generation) in Martha Tilaar Group and PT MustikaRatu Tbk. On the other hand, others were facing problems that lead to bankruptcy, which Nyonya Meneer is one of them. Nyonya Meneer declared bankrupt due to its nonperforming loans (Detik Finance). Previous studies found that CEO education which graduated from a prestigious university and has a master's degree or more significantly increases the firm's performance since they can develop better strategies [12]Furthermore, a study in Thailand found that CEO with business expertise also has a positive effect on a firm's financial performance [13]

We examine the influence of family ownership of the Indonesian publicly listed family firms on foreign investment and compare the effect of firms within a group with the standalone ones. Furthermore, we also investigate the effect of CEOs' characteristics such as CEO founder and CEO descendant, the level of CEO education and CEO's business expertise on foreign investment. The remainder of the paper is as follows. Section 2 presents a brief of relevant literature review and hypothesis development, follows by research methodology in Section 3. Section 4 describes the results and discussion. Section 5 concluded the paper.

\section{Literature Review}

A study in India observes how founders affect foreign investment by constructing two theories, i.e., entrenchment and alignment effect. Entrenchment effect arises due to the power to separate ownership and control rights [14] Therefore, it becomes more difficult for outsiders to monitor these firms' activities, especially when founders also control information flow to outsiders [15] Therefore, the expropriation risk will be higher. These arguments advocate that firms with higher 
founder ownership coupled with weak governance mechanisms require reasonably extra supervision, thereby requiring more monitoring cost.

In contrast, an alignment effect based on the monitoring role of foreign investors who bring fresh capital and global-level monitoring activity to be shared with the host country, particularly emerging markets [1] As a result, foreign investors can integrate ownership structure in emerging markets with a global-standard [16]. A study in Kores suggests control-ownership disparity as a form of controlling shareholders on foreign investment. Control-ownership disparity defines as the difference between cash flow rights and control rights. Control ownership disparity occurs when several shareholders of a company have a voting power greater than equity ownership. High control-ownership disparity indicates that controlling shareholders can own and use their voting rights over equity ownership and vice versa. Therefore, foreign investors become more anxious to face the risk of expropriation. As a result, they tend to decrease their investment [7] Thus, the hypothesis is as follows.

H1: There is a negative influence of family ownership on foreign investment in Indonesian publicly listed firms.

The emergence of a group or business group is driven by an inefficient capital market that needs an internal capital market that can fulfill the companies' needs [1]. The second hypothesis is based on several studies which found that there was more significant lack of transparency and the higher risk of expropriation in business groups compared to standalone firms [17] and [14] A study found that firms in a group of business tend to have a significant influence on foreign investment than standalone firms [7] The hypothesis is as follows.

$\mathrm{H} 2$ : There is a greater influence of family ownership in firm within a group than a standalone firm on foreign investment.

[18]According to Hambrick [18]the best way to understand why an organization is doing a thing or taking a decision is to consider how the behavior of the main actors in the company, namely the president director. The basis of this theory caused by the character of the chief director as part of management that can determine the firm's performance [18]. [19] and [20]find that the risk is higher when led by the founder than the offspring, this is because the founders tend to prefer to take risks. In contrast, Molly et al. [21]found that companies that were led by founders had lower leverage when compared to companies led by descendants of the founder.

Garcia-Ramos \& Garcia-Olalla [22] conducted a study on the impact of the characteristics of directors on the performance of family firms in Europe led by CEO founder and CEO descendant. The results show the company that led by the CEO descendants has a better performance than those led by CEO founders. Regarding the board of directors' size and independent directors, Yeh [23]found that there was a negative and significant influence between board size and foreign institutional investment. Thus, the hypothesis is:

\section{H3: CEO founder and CEO descendant affect foreign investment in family firms}

[24]One of the CEO's characteristics is their educational background [24]. Some studies found that CEOs with post-graduate education tend to lessen the firm's performance, due to the overconfidence of bias and too much R \& D activity [25], [13],[1]in his study using fractional logistic regression found that $R \& D$ activity can reduce the value of foreign investment in the company. Conversely, one study found that firms with high CEO education levels have a positive 
impression on the stock market that creating abnormal returns [26]In addition, other study found that there is a positive influence of CEOs who have degrees from a prestigious university and CEO with MBA degrees on a firm's financial performance [12] and therefore attract more foreign investment [1] Therefore, the hypothesis is proposed as follows:

H4: CEO's education affects foreign investment in family firms.

Sitthipongpanich \& Polsiri [13] also found that business expertise of the family CEO has a positive and significant influence on a firm's value. In addition, firms with the higher value will attract more foreign investment [1]Therefore, the hypothesis is:

$\mathrm{H} 5$ : $\mathrm{CEO}$ with business expertise will increase foreign investment in a family firm

\section{Research Methodology}

This study collected data from 76 listed Indonesian family firms, excluded non-financial, nonutility, and non-stated owned family firms for the period of 2003 to 2016. All the data are taken from each companies' annual report, Indonesian Capital Market Directory, and Thompson Reuters DataStream. In total, there is 882 observation that divided into two categories: group, and standalone firms. The empirical model of this study is as follows:

ForeignInvestment $_{i t}=a-\beta_{1}$ Family0wnership $_{i t}+\beta_{2}$ Founder Descendant $+\beta_{3}$ Education $_{i t}$

$+\beta_{4}$ Background $_{i t}+\delta$ controlvariables $+\varepsilon_{i t}$

Based on the Haussman test, we used random effect model to estimate the model and test the hypotheses. Table 1 summaries variables used in this study and their measures, as well as the references.

Table 1: Variable specification 


\section{Results}

This section presents the results of this study that comprises descriptive statistics of the data in Table 1, and analysis of the findings in Table 3, and Table 4 respectively.

Table 2 shows the summary statistics of the data used in this study. It shows that PT Hero Supermarket, Tbk has the highest percentage of foreign investment in 2009 which is 95.82 percent due to the previous release of the company's shares to a Hong Kong-based company, Mulgrave Corporation B.V. Meanwhile, the largest family ownership is in PT Tempo Scan Pacific Tbk with a value of 95.14 percent. It soared from 71.35 percent in the previous year. The highest value of the CEO's level of education is 21 where the CEO is a professor from PT Berlina Tbk; PT Humpuss Intermoda TransportasiT bk; CEO of PT Mustika Ratu Tbk. The minimum value of the CEO's level of education is 6 which means that the latest education of the CEO is Elementary School (SD) or equivalent of PT Alumindo Light Metal Industry Tbk and PT Indal Aluminium Industry Tbk.

Table 2: Summary Statistics

\begin{tabular}{lrrrr}
\hline \multicolumn{1}{c}{ Variable } & Mean & $\begin{array}{c}\text { Standard } \\
\text { Deviation }\end{array}$ & Maximum & Minimum \\
\hline Foreign Investment & 0,1842 & 0,2484 & 0,9582 & 0,0000 \\
Family Ownership & 0,5638 & 0,1635 & 0,9514 & 0,2501 \\
Founder & 0,5329 & 0,4992 & 1 & 0 \\
Descendant & 0,2074 & 0,4057 & 1 & 0 \\
Education & 16,2506 & 2,5807 & 21,0000 & 6,0000 \\
Background & 0,8231 & 0,3818 & 1 & 0 \\
Size & 20,8988 & 1,6704 & 25,2988 & 17,1312 \\
Leverage & 0,5157 & 0,2697 & 2,3292 & 0,0355 \\
ROA & 0,0633 & 0,0779 & 0,4344 & $-0,5918$ \\
Tobin's Q & 1,1595 & 0,7424 & 6,5072 & 0,1386 \\
Dividend & $6,66 \mathrm{e}+07$ & $2,71 \mathrm{e}+08$ & $5,00 \mathrm{e}+09$ & 0 \\
Current Ratio & 2,2939 & 3,7721 & 85,4100 & 0,1600 \\
Board Size & 4,7041 & 1,9418 & 2 & 12 \\
\hline
\end{tabular}

Table 3 presents the results of the hypotheses testing as regard to testing the effect of family ownership, CEO characteristics, CEO education, and CEO business expertise. The results in Table 3 shows that family ownership reduces foreign investment. This situation may cause due to a low transparency and less corporate disclosure thus, high monitoring costs[9] which cause foreign investors left the firms [4]. This finding also in line with Hammouda [27]This result supported the entrenchment effect where the greater the value of family ownership the lower the value of foreign investment in the firm [1]Foreign investors prefer companies with low control-ownership disparities, reflecting that foreign investors are sensitive to the corporate governance [7].

Table 3:The effect of family ownership, CEO characteristics, CEO education, and CEO business exnertice

\begin{tabular}{lrr}
\hline Dependent Variable & \multicolumn{2}{c}{ Foreign Investment } \\
\hline Independent Variable & \multicolumn{2}{c}{ Full Model } \\
\hline & \multicolumn{2}{c}{ Random Effect Model } \\
\cline { 2 - 3 } Constant & 0,4068731 & 0,037 \\
Family Ownership & $-0,6855362^{* * *}$ & 0,000 \\
Founder & $-0,0161295$ & 0,508 \\
Descendant & 0,0369373 & 0,132 \\
Education & $0,0147838^{* *}$ & 0,020 \\
Background & $-0,037499$ & 0,271 \\
Size & 0,0014517 & 0,851 \\
Leverage & $-0,0240531$ & 0,460 \\
ROA & $-0,3074092^{* * *}$ & 0,000 \\
TobinsQ & 0,0002436 & 0,979 \\
Dividend & $-5,17 \mathrm{e}-11$ & 0,043 \\
CurrentRatio & $-0,0010736$ & 0,449 \\
BoardSize & $-0,013344^{* *}$ & 0,013 \\
CrisisYearDummy & $0,0324114^{* * *}$ & 0,002 \\
\hline R-squared & & \\
\multicolumn{1}{c}{$\quad$ within } & 0,1892 & \\
$\quad$ - between & 0,1455 & \\
Prob (chi2) & 0,1955 & \\
No. Observation & 0,000 & \\
\hline * & 882 & \\
\hline
\end{tabular}

*signifikan pada tingkat $10 \%$ 
Table 4: The effect of family ownership of standalone and firms in a business group on foreign investment

\begin{tabular}{|c|c|c|c|c|}
\hline \multirow{3}{*}{$\begin{array}{l}\text { Dependent Variable } \\
\text { Independent Variable } \\
\text { Independent Variable }\end{array}$} & \multirow{2}{*}{\multicolumn{4}{|c|}{$\begin{array}{c}\text { Foreign Investment } \\
\text { Random Effect Model }\end{array}$}} \\
\hline & & & & \\
\hline & & \multicolumn{2}{|c|}{ Standalone } \\
\hline & Coef & Prob & Coef & Prob \\
\hline Constant & 0,5843905 & 0,024 & 0,1001886 & 0,747 \\
\hline Family Ownership & $-0,6217912^{\cdots}$ & 0,000 & $-0,9551645^{\cdots} \cdots$ & 0,000 \\
\hline \multicolumn{5}{|l|}{ R-squared } \\
\hline within & 0,1569 & & 0,3220 & \\
\hline between & 0,1806 & & 0,1021 & \\
\hline overall & 0,2097 & & 0,1675 & \\
\hline Prob (chi2) & 0,000 & & 0,000 & \\
\hline No. Observation & 522 & & 360 & \\
\hline
\end{tabular}

The results in Table 3 also find that both founders and descendant have a weak effect on foreign investment. In contrast, the higher the CEO education level will increase foreign investment. This finding supports Hitt \& Tyler [28]which found that top-level managers with a high level of education contribute positively to corporate innovation since they can develop a better strategy [12]In fact, there are some family firms

Hypothesis 2 aims to test the effect of family ownership of standalone and firms in a business group on foreign investment. The results in Table 4 indicate that family ownership which standalone firms has a greater impact compared to firms in a business group. This finding implies that there is a higher entrenchment effect felt by a standalone firms to that of the firm in a business group. The reason underlying this result is that companies in the business group have greater access to foreign capital, a better technology, and higher reputation [16] For example, PT Tjiwi Kimia Tbk, a member of Sinar Mas Group grown rapidly and becoming a market leader in the domestic market and has also successfully internationally. In fact, there are some family firms lead by CEO with doctoral degrees. For example, PT Humpuss Intermoda Transportasi Tbk, with the percentage of foreign investment reaching 53 to 78 percent. On the other hand, PT Alumindo Light Metal Industry Tbk and PT Indal Aluminium Industry Tbk led by the CEO with elementary education, have only less than five percent of foreign investment. Therefore, it can be concluded that level of education have a positive and significant impact on foreign investment.

Finally, profitability (ROA), dividend, board size, and crisis year has a significant impact on foreign investment. the results indicate that the firm's profitability will lessen foreign investment. Result regarding the negative effect of ROA can be attributed to one possible type of bias which is confirmation bias, where investors seek supporting information for their previous opinion about the firm [29] In addition, a higher dividend tends to reduce foreign investment. This finding consistent with the signaling theory of dividends [30]The theory suggests that firms that pay dividends will reduce the opportunity for investing in the profitable project, therefore cutback foreign investment. In addition, there is a negative and significant influence of board size on foreign investments due to the fact that the increasing number of directors will lead to poor communication problems and poor coordination problems [23]. Finally, there is a positive influence of the crisis year on foreign investment since the firms need additional capital from foreign investors to keep doing the business [31]

\section{Conclusion}

This study aims to investigate the effect of family ownership and CEO characteristics on foreign investment in Indonesian publicly listed family firms. This study finds that the higher the percentage of family ownership in the family firm, the lower foreign investors' shares in the firm. 
Some of the reasons are a greater expropriation risk and lack of information that foreign investors' get. The negative effect is higher in standalone firms compared to a firm in a business group, due to the group's better reputation. For CEO characteristics, there is a positive and significant influence of the CEO's level of education on foreign investment in the family firms. Lastly, there is no influence of CEO founders and CEO descendants and CEO's business expertise on foreign investment.

\section{References}

[1] Y. Chauhan and S. Kumar, Does founder ownership affect foreign investments? 2017.

[2] J. an. V. Batten and X.-V., in Foreign Ownership in Emerging Stock Markets, 2015.

[3] R. Aggarwal, L. Klapper, and P. D. Wysocki, "Portfolio preferences of foreign institutional investors," Journal of Banking and Finance, vol. 29, no. 12, pp. 2919-2946, 2005.

[4] C. Leuz, K. V. Lins, and F. E. Warnock, "The Society for Financial Studies Do Foreigners Invest Less in Poorly Governed Firms?," Lins and Francis E. Warnock Published, vol. 22, 2016.

[5] S. A and V. R W, "Large Shareholders and Corporate Control, 94(3), 461-488.," 1986.

[6] C. Andres, "Large Shareholders and Firm Performance - An Empirical Examination of Founding-Family Ownership," Journal of Corporate Finance, vol. 14, 2008.

[7] Y. Lee and M. Cho, "Does control-ownership disparity matter to foreign investors in Korea?," International Review of Economics and Finance, vol. 44, pp. 219-231, 2016.

[8] P. Coopers, Family Business Survey 2014: Indonesia. Findings for Indonesia. 2014.

[9] E. Mulyani, H. Singh, and S. Mishra, "Dividends, leverage, and family ownership in the emerging Indonesian market," Journal of International Financial Markets, Institutions and Money, vol. 43, pp. 16-29, 2016.

[10] S. Claessens and J. P. H. Fan, "Corporate Governance in Asia: A Survey," Asia-Pacific Development Journal, vol. 11, pp. 1-31, 2002.

[11] M. L. Mace., "Directors: Myth and Reality," Pp, vol. 403, no. 1, p. 207., 1972.

[12] S. Darmadi, "Board members' education and firm performance: evidence from a developing economy," International Journal of Commerce and Management, vol. 23, no. 2, pp. 113135, 2013.

[13] T. Sitthipongpanich and P. Polsiri, "Do CEO and board characteristics matter? A study of Thai family firms," Journal of Family Business Strategy, vol. 6, no. 2, pp. 119-129, 2015.

[14] M. Bertrand, "Ferreting Out Tunneling: An Application to Indian Business Groups," The Quarterly Journal of Economics, vol. 117, no. 1, pp. 121-148, 2002.

[15] J. P. H. Fan and T. J. Wong, "Corporate ownership structure and the informativeness of accounting earnings in," East Asia. Journal of Accounting and Economics, vol. 33, no. 3, pp. 401-425, 2002

[16] T. Khanna and K. Palepu, "The Future of Business Groups in Emerging Markets: Long-Run Evidence from Chile The Future Of Business Groups In Emerging Markets Kong-Run Evidence From Chi.e," Source: The Academy of Management Journal Academy of Management Journal, vol. 43, no. 3, pp. 268-285, 2000.

[17] A. J. Baek, J. Kang, and I. Lee, "American Finance Association Business Groups and Tunneling : Evidence from Private Securities Offerings by Korean Chaebols," The Journal of Finance, vol. 61, no. 5, pp. 2415-2449, 2006.

[18] D. C. Hambrick, "Upper Echelons Theory: An Update," Academy of Management Review, vol. 32, no. 2, pp. 334-343, 2007. 
[19] M. González, A. Guzmán, C. Pombo, and T., "Family firms and debt: Risk aversion versus risk of losing control," Journal of Business Research, pp. 1-29, 2012.

[20] W. S. Schulzea, M. H. Lubatkin, and R. N. Dino, "Toward a Theory of Altruism in Family Firms," Journal of Business Venturing, vol. 18, pp. 473-490, 2003.

[21] V. Molly, E. Laveren, and M. Deloof, "Family business succession and its impact on financial structure and performance," Family Business Review, vol. 23, no. 2, pp. 131-147, 2010.

[22] Garcia-Ramos and Garcia-Olalla, Journal of Family Business Strategy Board characteristics and firm performance in public founder- and nonfounder-led family businesses, vol. 2. 2011.

[23] C. M. Yeh, "Does board governance matter for foreign institutional investors to invest in listed tourism firms?," Tourism Management, vol. 68, pp. 66-78, 2018.

[24] A. . Gottesman and M. R. Morey, "CEO educational background and firm financial performance," Journal of Applied Finance, vol. 2, pp. 70-82, 2010.

[25] C. Ho Ying and Y. Chui Mei, "CEO Education and Firm Performance: Evidence from Hong Kong," Kong Baptist University, Hong, Apr. 2014.

[26] K. W. Erlim and R. Juliana, "Pengaruh Tingkat Edukasi Dan Spesialisasi Pendidikan CeoTerhadap Performa Perusahaan Di Indonesia," JurnalManajemen Maranatha, vol. 16, no. 2, pp. 177-186, 2017.

[27] A. Hammouda, "How Can Family Firms Attract Foreign Investors? The Role of Governance," in Mechanisms in Tunisia, 2017.

[28] M. A. Hitt and B. B. Tyler, "Strategic decision models: Integrating different perspectives," Strategic Management Journal, vol. 12, no. 5, pp. 327-351, 1991.

[29] H. Shefrin, Behavioral Corporate Finance: Decisions That Create Value. 2007.

[30] J. Lintner, "Distribution of Incomes of Corporations Among Dividens," Papers and Proceedings of the Sixty-eighth Annual Meeting of the American Economic Association, vol. 46, no. 2, pp. 97-113, 1956.

[31] M. Rasyidin, "Analisis Hubungan Dinamis Antara Foreign Capital In flows dan Pasar Saham di," Indonesia, vol. 1, no. 1, pp. 1-18, 2015. 